\title{
Kandungan klorofil dan karotenoid Kacang Tunggak (Vigna unguiculata (L.) Walp.) pada umur tanaman yang berbeda
}

\author{
Contents of chlorofil and carotenoid of beans (Vigna unguiculata (L.) Walp.) \\ in the different age of plants
}

\author{
Ika Susanti Hendriyani ${ }^{1}$, Yulita Nurchayati ${ }^{2 *}$, dan Nintya Setiari ${ }^{3}$ \\ ${ }^{1,2,3}$ Departemen Biologi, Fakultas Sains dan Matematika Universitas Diponegoro \\ Jl. Prof. H. Soedarto, SH., Tembalang Semarang 50275 Indonesia
}

\begin{abstract}
ABSTRAK
Klorofil merupakan pigmen fotosintesis yang juga dapat dimanfaatkan manusia sebagai obat kanker otak, paru-paru, dan mulut, serta dapat digunakan sebagai desinfektan, antibiotik dan suplemen makanan, sedangkan karotenoid bermanfaat sebagai antioksidan. Kandungan kedua pigmen tersebut sangat dipengaruhi oleh umur tanaman, khususnya bagi tanaman sayuran yang dimanfaatkan daunnya seperti kacang tunggak (Vigna unguiculata (L.) Walp.). Tujuan dari penelitian ini adalah untuk mengetahui pola kandungan klorofil dan karotenoid daun kacang tunggak selama fase pertumbuhan dan untuk mengetahui umur tanaman yang tepat untuk pemanenan kacang tunggak sehingga diperoleh kandungan klorofil dan karotenoid tertinggi. Bibit kacang tunggak diperoleh dari biji yang dikecambahkan kemudian ditanam dalam pot berisi media tanam siap pakai di dalam rumah kaca. Analisis klorofil dan karotenoid dilakukan pada umur tanaman yang berbeda dari umur 1 sampai 11 minggu. Desain penelitian yang digunakan adalah Rancangan Acak Lengkap. Data dianalisis dengan menggunakan analisis varians, dan dilanjutkan dengan uji Duncan pada taraf signifikansi 95\%. Hasil penelitian menunjukkan bahwa kandungan klorofil dan karotenoid tertinggi dihasilkan oleh daun kacang tunggak pada fase vegetatif atau sebelum waktu pembungaan. Kandungan klorofil tertinggi diperoleh pada tanaman umur 4 minggu HST, sedangkan kandungan karotenoid tertinggi diperoleh pada tanaman umur 3 minggu HST.
\end{abstract}

Kata kunci: klorofil, karotenoid, kacang tunggak, umur tanaman

\begin{abstract}
Chlorophyll is a pigment of photosynthesis which is also efficacious as a cure for brain, lung, and oral cancer, and can be used as a disinfectant, antibiotic and dietary supplement, while carotenoids are useful as antioxidants. The content of the two pigments is strongly influenced by the age of the plant, especially for vegetable crops used in leaves such as cowpea (Vigna unguiculata (L.) Walp.). The purpose of this research is to know the pattern of chlorophyll content and carotenoid of cowpea leaf during the growth phase and to know the age of the right plant for harvesting cowpea so that the highest chlorophyll and carotenoid content is obtained. Cowpea seeds obtained from seeds are added then planted in pots containing ready-made planting media in the greenhouse. Chlorophyll and carotenoid analyzes were performed at different plant ages from 1 to 11 weeks. The research design used is Completely Randomized Design. Data were analyzed using variance analysis and continued with Duncan test at $95 \%$ significance level. The results showed that the highest chlorophyll and carotenoid content was produced by the cowpea leaf in the vegetative phase or before the flowering time. The highest chlorophyll content was obtained at 4WAP (weeks after planting) of age crop, while the highest carotenoid content was obtained in $3 \mathrm{WAP}$.
\end{abstract}

Keywords: Chlorophyll, carotenoid, Vigna unguiculata (L.) Walp., age of plants

\section{Pendahuluan}

Klorofil merupakan zat hijau daun yang terdapat pada semua tumbuhan hijau sebagai pigmen fotosintesis yang utama. Klorofil juga mempunyai banyak manfaat lain bagi manusia yaitu sebagai obat kanker otak, paru-paru, dan

\footnotetext{
* Penulis korespondensi:

E-mail: yulita.yoko@gmail.com
}

Hak cipta @ 2018, Jurnal Biologi Tropika, e-ISSN 2614-8323

Tersedia online di http://ejournal2.undip.ac.id/index.php/jbt 
mulut (Limantara, 2006). Klorofil juga dapat digunakan sebagai desinfektan, antibiotik dan suplemen makanan (Anonim, 2007). Kacang tunggak (Vigna unguiculata (L.) Walp.) merupakan tanaman jenis legum yang dapat digunakan sebagai alternatif sumber klorofil selain alfalfa dan alga, yang sudah terlebih dahulu dimanfaatkan sebagai suplemen makanan. Hal ini didasarkan oleh karena kacang tunggak merupakan tanaman legum yang banyak dibudidayakan di Indonesia, serta daunnya banyak dikonsumsi sebagai sayuran. Selain itu, kacang tunggak memiliki kandungan klorofil tertinggi dibandingkan beberapa legum yang lain, yaitu kecipir, alfalfa, kacang panjang, dan buncis yang ditanam di Jawa Tengah (Sarmita, 2008). Kelebihan kacang tunggak yang lain adalah jenis legum tersebut merupakan tanaman semusim sehingga lebih cepat panen. Kacang tunggak juga toleran terhadap hama polong, dapat tumbuh pada lahan kering, lahan sawah, dan lahan masam sehingga mudah dalam pemeliharaannya (Iska, dkk., 2018).

Pigmen lain yang ada dalam tanaman selain klorofil adalah karotenoid. Karotenoid merupakan suatu senyawa terpenoid yang menjadi pigmen fotosintesis dengan efek warna yang berkisar antara merah dan kuning (CaneneAdams et al., 2005; Dewick, 2002). Violaxanthin, suatu xantofil, merupakan anggota karotenoid yang ditemukan pada membran kloroplas yang menyebabkan warna kekuningan. $\beta$-karoten dan lutein dari xantofil merupakan karotenoid yang ditemukan pada tilakoid sebagian besar tumbuhan (Janik et al., 2008). Karotenoid pada beberapa bunga dan buah merupakan pigmen yang dominan. Warna karotenoid pada daun tidak begitu terlihat karena tertutup oleh klorofil yang jauh lebih banyak. Apabila kandungan klorofil dalam daun berkurang, karotenoid mulai tampak dan menghasilkan warna kuning dan merah pada daun-daunnya (Hopkins \& Norman, 2008).

Kandungan klorofil dan karotenoid pada suatu tanaman dipengaruhi oleh umur tanaman. Kandungan klorofil umumnya akan meningkat pada fase awal pertumbuhan atau fase vegetatif. Kandungan klorofil akan menurun pada fase penuaan. Karotenoid pada daun sebagai pigmen asesoris fotosintesis, umumnya akan meningkat pada saat kandungan klorofil menurun (Yang et al., 2014). Usaha untuk memperoleh kandungan klorofil dan karotenoid yang tinggi dalam suatu tanaman terus dilakukan dalam upaya untuk memproduksi klorofil dan karotenoid. Tujuan penelitian ini adalah untuk mempelajari pola kandungan klorofil dan karotenoid kacang tunggak selama fase pertumbuhan serta mengetahui umur tanaman yang tepat untuk pemanenan kacang tunggak sehingga diperoleh kandungan klorofil dan karotenoid tertinggi.

\section{Metodologi}

\section{Persiapan bibit kacang tunggak dan seleksi tanaman}

Biji kacang tunggak direndam dalam akuades selama 24 jam kemudian dikecambahkan dalam media tanam dalam pot. Masing-masing pot berisi 5 biji hingga muncul daun di permukaan. Bibit yang berumur 1 minggu, dipilih 1 tanaman yang memiliki tinggi dan jumlah daun yang sama dari masing-masing pot. Penanaman dilakukan selama 11 minggu. Pemeliharaan dilakukan dengan melakukan penyiraman setiap 2 hari sekali dengan volume penyiraman yang sama yaitu $200 \mathrm{~mL}$ pada masing-masing pot.

\section{Pola pertumbuhan dan kandungan pigmen}

Variabel pertumbuhan meliputi tinggi tanaman, berat basah, berat kering tanaman dan kandungan pigmen dari sampel daun tanaman kacang tunggak yang diukur pada tananan umur 1 sampai 11 minggu setelah tanam (HST). Setiap pengamatan dilakukan dengan 3 ulangan.

\section{Penghitungan klorofil dan karotenoid}

Kandungan klorofil total dan karotenoid diukur dengan menggunakan metode spektrofotometri. Analisis klorofil dan karotenoid dilakukan tiap minggu, mulai tanaman berumur 1 sampai 11 minggu. Daun tanaman pada urutan 3-4 dari pucuk diambil dan ditimbang menggunakan timbangan analitik seberat 1g, lalu daun dihaluskan menggunakan mortar kemudian diektraksi dengan 100ml aseton 80\% diaduk hingga klorofil dan karotenoid larut. Ekstrak tersebut disaring dengan kertas saring. Filtrat yang didapat ditempatkan dalam kuvet untuk selanjutnya diukur kandungan klorofil total dan karotenoidnya menggunakan spektrofotometer (SHIMADZU UVmini 1240) pada panjang 
gelombang 480nm, 645nm dan 663nm (Kurniawan, et al., 2010). Kandungan klorofil total dan karotenoid dapat dihitung menggunakan rumus:

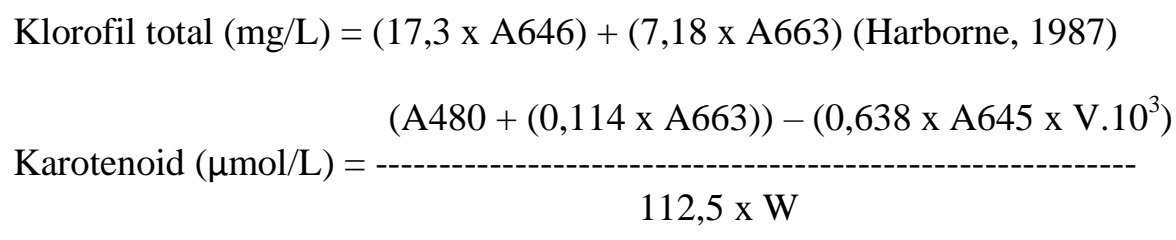

$1 \mu \mathrm{mol} / \mathrm{L}=27,25 \mathrm{mg} / \mathrm{L}$

(Hendry \& Grime, 1993)

\section{Hasil}

\section{Pertumbuhan kacang tunggak}

Variabel pertumbuhan kacang tunggak ditunjukkan dengan pertambahan tinggi tanaman, berat basah dan berat kering tanaman. Selama 11 minggu pertumbuhan kacang tunggak mengalami beberapa fase yaitu fase lag, fase percepatan dan fase logaritmik.

Tabel 1. Rata-rata tinggi tanaman $(\mathrm{cm})$, berat basah $(\mathrm{g})$, dan berat kering $(\mathrm{g})$ kacang tunggak (V. unguiculata (L.) Walp.)

\begin{tabular}{cccc}
\hline Umur Tanaman (minggu) & \multicolumn{3}{c}{ Pertumbuhan } \\
\cline { 2 - 4 } & $\mathrm{T}(\mathrm{cm})$ & $\mathrm{BB}(\mathrm{g})$ & $\mathrm{BK}(\mathrm{g})$ \\
\hline 1 & $9.85^{\mathrm{a}}$ & $0.48^{\mathrm{a}}$ & $0.03^{\mathrm{a}}$ \\
2 & $11.4^{\mathrm{a}}$ & $0.78^{\mathrm{ab}}$ & $0.07^{\mathrm{a}}$ \\
3 & $15.70^{\mathrm{ab}}$ & $1.67^{\mathrm{ab}}$ & $0.16^{\mathrm{a}}$ \\
4 & $15.98^{\mathrm{ab}}$ & $1.52^{\mathrm{ab}}$ & $0.17^{\mathrm{a}}$ \\
5 & $17.27^{\mathrm{ab}}$ & $2.64^{\mathrm{ab}}$ & $0.32^{\mathrm{a}}$ \\
6 & $18.83^{\mathrm{ab}}$ & $3.95^{\mathrm{bc}}$ & $0.43^{\mathrm{ab}}$ \\
7 & $21.90^{\mathrm{ab}}$ & $6.01^{\mathrm{cd}}$ & $0.53^{\mathrm{ab}}$ \\
8 & $27.35^{\mathrm{ab}}$ & $8.20^{\mathrm{d}}$ & $0.91^{\mathrm{b}}$ \\
9 & $31.97^{\mathrm{b}}$ & $18.49^{\mathrm{f}}$ & $2.42^{\mathrm{c}}$ \\
10 & $67.83^{\mathrm{c}}$ & $15.10^{\mathrm{e}}$ & $3.39^{\mathrm{d}}$ \\
11 & $94.83^{\mathrm{d}}$ & $30.36^{\mathrm{g}}$ & $3.94^{\mathrm{e}}$ \\
\hline
\end{tabular}

Keterangan: Angka-angka yang diikuti superskrip yang berbeda, dalam satu kolom yang sama, menyatakan berbeda nyata berdasarkan uji Duncan pada taraf kepercayaan $95 \%$.

\section{Pola Kandungan Klorofil Total dan Karotenoid}

Kandungan klorofil dan karotenoid selama 11 minggu menunjukkan pola yang serupa. Tanaman umur 3 minggu sedang memasuki fase vegetatif. Pertumbuhan berlangsung optimal dan ditandai dengan pertambahan biomassa. Cahaya matahari dan kondisi lingkungan yang memadai tidak hanya mendukung proses fotosintesis, tetapi juga pembentukan klorofil. Kandungan klorofil sangat dipengaruhi oleh faktor genetik. Kandungan klorofil pada daun kacang tunggak mencapai nilai tertinggi diantara daun kacang kecipir, kedelai, kacang buncis dan kacang panjang (Sarmita, 2008). Selain klorofil, pigmen fotosintesis yang lain yakni karotenoid, juga menunjukkan konsentrasi tertinggi pada umur 3 minggu. Tampak bahwa kedua pigmen fotosintetik berperan maksimal.

Peningkatan jumlah klorofil kembali terjadi pada umur tanaman 8 minggu sampai 10 minggu setelah tanam atau pada fase linier. Hal ini diduga karena pada minggu tersebut mulai terbentuk polong. Hopkins \& Norman (2008) menyatakan bahwa pada masa pembentukan polong atau masa generatif, kacang tunggak membutuhkan fotosintat yang lebih banyak dibandingkan pada masa vegetatif. 
Penurunan kandungan karotenoid terjadi pada fase logaritmik yaitu pada umur tanaman 4 minggu sampai 7 minggu. Hal ini diduga karena pada minggu tersebut terjadi penumpukan hasil fotosintat yang akan digunakan oleh tanaman untuk proses pembungaan. Penumpukan hasil fotosintat tersebut menghalangi penyerapan cahaya oleh daun. Kandungan karotenoid kembali mengalami peningkatan pada umur tanaman 8 sampai 10 minggu atau pada fase linier. Hal ini diduga karena pada umur tersebut merupakan waktu terbentuknya polong pada tanaman kacang tunggak. Peningkatan kandungan karotenoid umur 8 sampai 10 minggu setelah tanam berbeda tidak nyata.

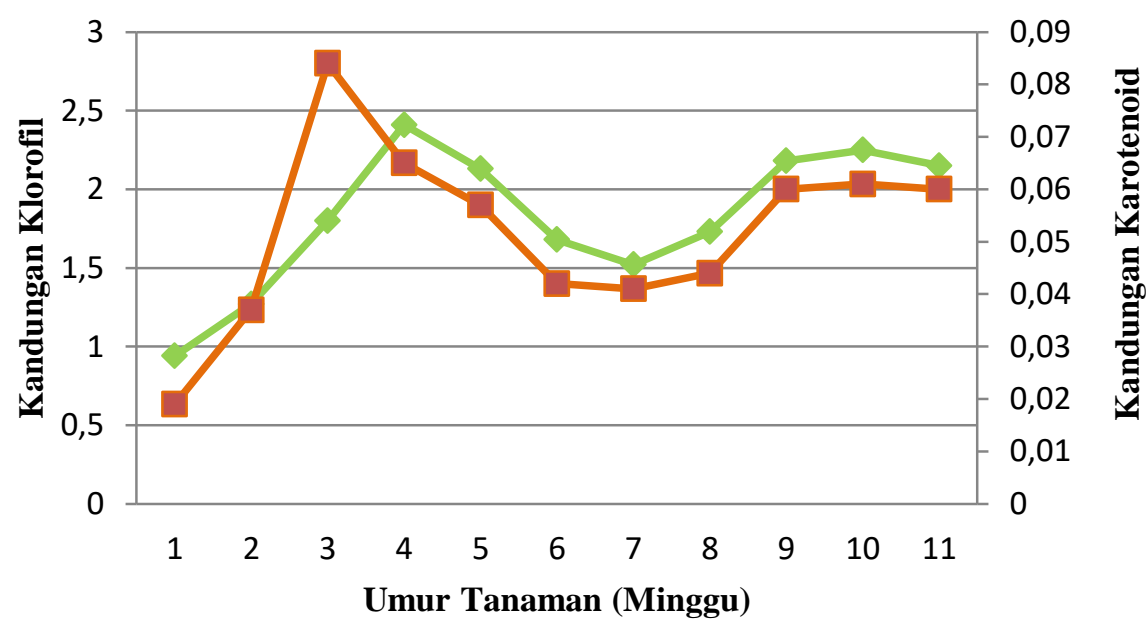

$\rightarrow$ Klorofil total $(\mathrm{mg} / \mathrm{g}) \quad-$ Karotenoid $(\mathrm{mg} / \mathrm{g})$

Gambar 1. Kurva pola produksi klorofil total dan karotenoid daun kacang tunggak (V. unguiculata (L.) Walp.) pada umur tanaman yang berbeda

Gambar 1 menunjukkan bahwa kandungan klorofil total dan karotenoid kacang tunggak memiliki pola produksi yang sama mulai dari fase lag sampai fase linier. Secara genetis, kandungan karotenoid kacang tunggak tidak setinggi kandungan klorofilnya baik pada awal pertumbuhan maupun ketika memasuki fase pertumbuhan akhir. Hal ini diduga karena kacang tunggak merupakan tanaman hasil persilangan antar dua individu yang berbeda varietas sehingga dihasilkan kacang tunggak dengan sifat yang unggul antara lain dengan memproduksi pigmen dengan pola yang hampir sama selama pertumbuhannya. Hal ini sesuai dengan Trustinah \& Astanto (1998) yang menyatakan bahwa varietas KT 6 kacang tunggak merupakan hasil persilangan antara varietas lokal No. 191 dengan varietas introduksi VITA4 yang berasal dari IITA. Varietas KT 6 dimasukkan ke Indonesia tahun 1986 dengan nomor galur VITA4/191-91-B-33. Menurut Soedjono (2003), kacang tunggak merupakan tanaman hasil persilangan yang persilangannya dilakukan pertama kali pada tahun 1981 terhadap biji dengan dosis 300-500 Gy sinar gamma dan DMS yang meningkatkan produksi, keragaman ukuran dan warna biji.

\section{Pembahasan}

Berdasarkan kurva sigmoid pertumbuhan, ketiga variabel pertumbuhan kacang tunggak selama 11 minggu belum menunjukkan fase stationer (Tabel 1). Hal ini menandakan bahwa kacang tunggak berumur lebih dari 11 minggu. Tinggi tanaman mencapai fase pertumbuhan linier pada umur 9-11 minggu menandakan pada kisaran waktu tersebut menjadi fase vegetatif yang digunakan untuk menyiapkan tanaman memasuki fase reproduktif. Pada fase vegetatif, tanaman kacang tunggak membentuk sulur, sehingga meningkatkan tinggi tanaman. Peningkatan tinggi tanaman tampak diikuti dengan peningkatan berat basah dan berat keringnya.

Kacang tunggak merupakan tanaman semusim yang umumnya memulai fase reproduktif atau awal pembungaan pada umur 40-46 hari atau umur 7-8 minggu. Selanjutnya polong akan masak berumur 65 hari atau masa panen berkisar 65-70 hari. Namun demikian, fase pertumbuhan dan perkembangan tanaman tidak hanya ditentukan oleh faktor genetik, tetapi juga dipengaruhi faktor lingkungan. Hal ini mengindikasikan bahwa kacang tunggak pada 
penelitian ini memiliki fase vegetatif yang lebih panjang dari deskripsi benihnya. Diduga lokasi penanaman dan media tanam yang digunakan cukup mendukung pertumbuhan tanaman tersebut. Penanaman di dalam pot juga mempengaruhi jumlah unsur hara yang diperlukan bagi tanaman untuk melangsungkan proses pertumbuhan dan perkembangannya.

Kandungan klorofil sangat dipengaruhi oleh faktor genetik. Kandungan klorofil pada daun kacang tunggak mencapai nilai tertinggi diantara daun kacang kecipir, kedelai, kacang buncis dan kacang panjang (Sarmita, 2008). Selain klorofil, pigmen fotosintesis yang lain yakni karotenoid, juga menunjukkan konsentrasi tertinggi pada umur 3 minggu. Tampak bahwa kedua pigmen fotosintetik berperan maksimal. Hasil penelitian menunjukkan bahwa kandungan karotenoid mengalami peningkatan pada umur tanaman 1 minggu sampai 3 minggu atau pada fase lag. Peningkatan tersebut diduga karena pada minggu tersebut tanaman mengalami fase pertumbuhan awal dimana akan terjadi peningkatan produksi pigmen untuk proses fotosintesis. Hasil dari proses fotosintesis tersebut digunakan untuk proses pertumbuhan awal tanaman yaitu pembentukan organ-organ vegetatif. Menurut Hopkins \& Norman (2008), peran karotenoid dalam fotosintesis adalah membantu mengabsorbsi cahaya sehingga cahaya yang dipakai untuk proses fotosintesis menjadi lebih besar. Energi yang diserap oleh karotenoid diteruskan pada klorofil yang kemudian digunakan dalam fotosintesis.

Menurut Bramley (2002), cahaya berfungsi untuk meningkatkan aktivitas enzim yang berperan dalam biosintesis karotenoid. Berkurangnya cahaya yang diserap oleh daun menyebabkan terhambatnya biosintesis karotenoid pada daun. Hal ini diduga karena karotenoid merupakan pigmen yang membantu klorofil dalam penyerapan cahaya, sehingga jumlahnya tidak sebanyak klorofil. Pigmen karotenoid menyerap cahaya pada panjang gelombang yang berbeda dengan yang diserap klorofil. Jadi, karotenoid dan klorofil merupakan pigmen penerima cahaya yang saling melengkapi. Hal ini sesuai dengan Campell \& Reece (2002), bahwa karotenoid merupakan pigmen aksesoris yang membantu klorofil dalam proses fotosintesis. Kandungan relatif karotenoid dan klorofil bervariasi pada spesies tumbuhan.

Biointesis klorofil dipengaruhi oleh faktor cahaya. Cahaya dibutuhkan untuk mereduksi protoklorofilida a menjadi klorofilida a, dan selanjutnya membentuk klorofil a. Reduksi protoklorofilida a menjadi klorofilida a berlangsung dengan bantuan enzim POR (protochlorophyllide oxidoreductase) yang bekerja aktif bila terdapat cahaya. Rendahnya intensitas cahaya akan mengakibatkan penurunan metabolisme, sehingga karbohidrat yang dihasilkan juga mengalami penurunan. Karbohidrat merupakan metabolit primer yang menjadi senyawa awal pembentukan berbagai metabolit lain maupun molekul organik seperti klorofil (Banas et al., 2011)

Gambar 1. menunjukkan bahwa kandungan klorofil kacang tunggak mencapai nilai tertinggi pada awal pertumbuhan tanaman. Fase ini merupakan fase vegetatif, ditandai dengan pertambahan tinggi batang juga jumlah daun. Hal ini sesuai dengan Sardoei et al., (2014) yang menyatakan bahwa kandungan klorofil maksimal pada tanaman terdapat pada fase pertumbuhan vegetatif sebelum memasuki fase generatif. Kandungan karotenoid kacang tunggak juga mencapai nilai tertinggi pada umur tanaman sebelum berbunga. Diduga, karotenoid selain sebagai pigmen fotosintesis juga berfungsi untuk melindungi klorofil dari cahaya yang tinggi, sehingga kandungan karotenoid pada tanaman menyesuaikan dengan kandungan klorofilnya. Selain berperan sebagai pigmen penyerap cahaya yang bermanfaat bagi fotosintesis, karotenoid juga berfungsi melindungi klorofil dari kerusakan akibat oksidasi oleh $\mathrm{O}_{2}$ saat tingkat penyinaran tinggi. Suarni (2005) menyatakan bahwa bagi dunia kesehatan, $\beta$-karoten merupakan salah satu karotenoid yang memiliki aktivitas provitamin A yang tinggi. $\beta$-karoten dalam saluran pencernaan dikonversi oleh sistem enzim menjadi retinol, yang selanjutnya berfungsi sebagai vitamin A. Karotenoid lebih dikenal sebagai antioksidan untuk pencegahan infeksi dan menghambat terbentuknya kanker.

\section{Kesimpulan}

Kandungan klorofil total dan karotenoid daun kacang tunggak (Vigna unguiculata (L.) Walp.) menunjukkan pola yang sama. Nilai tertinggi kandungan klorofil dicapai pada umur 4 minggu HST, sedangkan karotenoid teringgi diperoleh pada umur 3 minggu HST. Kedua pigmen mencapai nilai maksimum pada umur vegetatif tanaman kacang tunggak. 


\section{Daftar Pustaka:}

Anonim. 2007. Klorofil. http://sicma.blogspot.com. Diakses 28 April 2018.

Banaś, A. K., Łabuz, J., Sztatelman, O., Gabryś, H., \& Fiedor, L. 2011. Expression of enzymes involved in chlorophyll catabolism in Arabidopsis is light-controlled. Plant Physiology, pp-111. doi.org/10.1104/pp.111.185504

Campbell, N. A. \& J. B. Reece. 2002. Biology. Sixth Edition, Pearson Education. Inc. San Francisco.

Canene-Adams K., Clinton, S. K., King, J. L., Lindshield, B. L., Wharton C., Jeffery, E. \& J.W. Jr. Erdman. 2005. The growth of the Dunning $R-3327-H$ transplantable prostate adenocarcinoma in rats fed diets containing tomato, broccoli, lycopene, or receiving finasteride treatment. FASEB J. 18: A886 (591.4).

Bramley, P. M. 2002. Regulation of Carotenoid Formation during Tomato Fruit Ripening and Development. Journal of Experimental Botany 377 (53):2107-2113. DOI: 10.1093/jxb/erf026

Harbone, J.B. 1987. Metode Fitokimia. Penerbit ITB. Bandung. P. 259-261.

Hopkins, W. \& H. Norman. 2008. Introduction to Plant Physiology $4^{\text {th }}$ Edition. USA : John Wiley \& Son.

Iska, F. R., Purnamawati, H., \& Kartika, J. G. 2018. Evaluasi Produktivitas Kacang Tunggak (Vigna unguiculata (L.) Walp) pada Dataran Menengah. Buletin Agrohorti, 6(2), 162-169. http://dx.doi.org/10.29244/agrob.6.2.171178

Janik, E., Grudziński, W., Gruszecki, W. I., \& Krupa, Z. 2008. The xanthophyll cycle pigments in Secale cereale leaves under combined $\mathrm{Cd}$ and high light stress conditions. Journal of Photochemistry and Photobiology B: Biology, 90(1), 47-52. doi:10.1016/j.jphotobiol.2007.10.006

Kurniawan, M., M. Izzati, \& Y. Nurchayati. 2010. Kandungan Klorofil Total, Karotenoid, dan Vitamin C pada Beberapa Spesies Tanaman Akuatik. Buletin Anatomi dan Fisiologi Vol. XVIII No.1 28-40. https://doi.org/10.14710/baf.v18i1.2614

Limantara, L. 2006. Klorofil si Emas Hijau. http;//www.synergizerteam.com. Diakses 28 April 2008.

Sardoei, A. S., Rahbarian, P., \& Shahdadneghad, M. 2014. Evaluation chlorophyll contents assessment on three indoor ornamental plants with plant growth regulators. European Journal of Experimental Biology, 4(2), 306310. http://www.imedpub.com/articles/evaluation-chlorophyll-contents-assessment-on-three-indoorornamentalplants-with-plant-growth-regulators.pdf

Sarmita, F. 2008. Kandungan Klorofil dan Pertumbuhan Beberapa Legum pada Ketinggian Tempat yang Berbeda. Skripsi. Jurusan Biologi FMIPA Undip.

Soedjono, S. 2003. Aplikasi Mutasi Induksi dan Variasi Somaklonal dalam Pemuliaan Tanaman. Balai Penelitian Tanaman Hias. Cianjur. https://www.researchgate.net/publication/242243438_APLIKASI_MUTASI_INDUKSI_DAN_VARIASI_SOM AKLONAL_DALAM_PEMULIAAN_TANAMAN

Suarni, 2005. Potensi Kandungan senyawa $\beta$-karoten Beberapa Komoditi sebagai Sumber Vitamin A. Balai Penelitian Tanaman Serealia. Maros.

Suzuki, J.Y., Bollivar, D.W. \& C.E. Bauer. 1997. Genetic Analysis of Chlorophyll Biosynthesis. Annu. Rev. Genet. 31: 61-89. https://doi.org/10.1146/annurev.genet.31.1.61

Trustinah, M. \& Astanto. 1998. Deskripsi Kacang Tunggak KT 6. Balai Benih BIOGEN. Bogor.

Yang, H., Li, J., Yang, J., Wang, H., Zou, J., \& He, J. 2014. Effects of nitrogen application rate and leaf age on the distribution pattern of leaf SPAD readings in the rice canopy. PloS one, 9(2), e88421. 